Diabetologia, Suppl. to 9, 364-366 (1973)

(C) by Springer-Verlag 1973

\title{
An Open Comparative Study of the Efficacy and Tolerance of a New Antidiabetic Agent: Glipizide
}

\author{
I. De Leeuw, H. De Baere, P. Decraene, P. Lemmens and H. Verhaegen \\ Antwerp Diabetes Study Group, Elf Novemberstraat, 43, 2060 Merksem, Belgium
}

Received: June 13,1973, and in revised form: June 29, 1973, accepted: July 1, 1973

\begin{abstract}
Summary. Glipizide is a sulfocyclohexylurea with proven antidiabetic properties. Glipizide treated patients have been compared during an initial period of three months with three groups of comparable patients receiving single agent therapy, viz. glibenclamide, chlorpropamide, or phenformin. The drug seems to be an easy-tohandle antidiabetic agent, active in a dosage from 2.5 to $20 \mathrm{mg}$ in patients with maturity-onset diabetes, not
\end{abstract}

satisfactorily controlled on diet alone. The frequency of primary failures was slightly higher than with glibenclamide and chlorpropamide, but on the contrary the tolerance was better and the side effects negligible.

Key words: Sulfonylurea compounds, glibenclamide, chlorpropamide, phenformin, glipizide, clinical trials, maturity-onset diabetes, oral treatment.
Glipizide is a new compound of the sulfonylurea type, synthetised by Ambrogi in 1971 [1]. This author concluded, after animal experimentation, that:

1. the compound was at least 100 times more potent than tolbutamide in decreasing blood glucose levels in fasted normal animals, and

2. the compound antagonized hyperglycemia induced by glucose loads and increased insulinemia [2].

Administration of the drug to non-diabetic [3] and diabetic subjects [4] demonstrates that glipizide, given in a daily dose of $2.5 \mathrm{mg}$ to $15.0 \mathrm{mg}$, is an effective blood sugar lowering drug and is well tolerated.

The objectives of our study were:

1. to determine the dosage of glipizide required by patients suffering from non-ketotic maturity-onset diabetes mellitus, not satisfactorily controlled with diet alone.

2. to establish the efficacy of short-term ( 3 months) therapy with glipizide and to determine the frequency of primary failures. The frequency of secondary failures will be studied during a long-term (12 months) study which is presently under way.

3. to establish the safety and toleration of therapy with glipizide; and

4. to compare the glipizide parameters with data from comparable patients treated during the same investigation with single-agent therapy, comprising either, glibenclamide, chlorpropamide or phenformin.

\section{Materials and Method}

Sixty patients of either sex suffering from nonketotic maturity-onset diabetes were allocated at random to four treatment groups receiving glipizide, glibenclamide, chlorpropamide or phenformin. In case of primary or secondary failure to the first allocated drug, the patient was crossed-over at random to one of the other agents after a transition period of $3-7$ days on diet alone. Each treatment was preceded by a suitable "diet alone" period during which the severity of the diabetes was determined. Only those patients showing unsatisfactory control when receiving an adequate diet were included in the study. The starting dose of glipizide was $2.5 \mathrm{mg} / \mathrm{d}$. This dose was adjusted by increments of $2.5-5 \mathrm{mg}$ every $3-7$ days up to a maximum dose of $20 \mathrm{mg} / \mathrm{d}$. The daily dose was preferably given immediately after breakfast or after the mid-day meal but in a few instances it was subdivided into two administrations. The comparative drugs were used according to the dosage schedule recommended for these agents. Patients were seen for an assessment visit weekly, or more often, during the initial period on diet alone and for the first four weeks of therapy with the trial drug; and/or until satisfactory control was achieved; then on a monthly basis. At each visit the clinical symptoms and signs, the body weight, the (FBS) fasting blood sugar and the values one and two hours post-prandially, as well as the $24 \mathrm{~h}$-glucose urinary excretion were recorded. Haematology, liver function, renal function and lipid metabolism were checked every month, the serum electrolytes every three months and the ECG and fundi at the beginning and at the end of each drug treatment period.

The degree of control of the diabetes during the "diet alone" and "diet plus trial drug" treatment periods was evaluated by measuring the FBS, the two and whenever possible ,the one hour post-prandial blood sugar level (PPBS) and the $24 \mathrm{~h}$ urinary glucose excretion. The degree of control was rated as either excellent, good, fair, poor or negative according to the criteria shown in Table 1. 


\section{Results and Discussion}

The results are summarised in Table 2 .

Out of a total of 60 patients, 7 were dropped from the study for various reasons (see table). Of the remaining 53, 42 were females, and 21 males, which is a proportion considered representative of maturityonset diabetes in West-European countries. In this group there were 27 newly-diagnosed diabetics.

We will now comment on the results in the four groups of patients. ministered. Indeed, all the patients successfully controlled with phenformin lost weight, compared with the weight after diet alone, and the best results were obtained in the patients with the greatest weight loss. Four of the five "primary failures" were not overweight at the time when phenformin treatment was started. Three had only a minimal weight loss $(1-4 \mathrm{~kg})$ and the other two (the only ones of the group) gained weight while on maximal phenformin doses.

An important factor was that four "primary failures" who were switched over to glipizide quickly

Table 1

\begin{tabular}{|c|c|c|c|c|}
\hline \multirow{2}{*}{$\begin{array}{l}\text { Therapeutic } \\
\text { results }\end{array}$} & \multicolumn{3}{|c|}{ Glycemia (Values in whole blood) } & \multirow[t]{2}{*}{ Glycosuria } \\
\hline & Fasting & $1 \mathrm{~h}$ p.p. & 2 h p.p. & \\
\hline Excellent & $\leq 110 \mathrm{mg} / 100 \mathrm{ml}$ & $\leq 150 \mathrm{mg} / 100 \mathrm{ml}$ & $\leq 130 \mathrm{mg} / 100 \mathrm{ml}$ & absent \\
\hline Good & $\leq 130 \mathrm{mg} / 100 \mathrm{ml}$ & $\leq 180 \mathrm{mg} / 100 \mathrm{ml}$ & $\leq 150 \mathrm{mg} / 100 \mathrm{ml}$ & $\leq \quad 5 \mathrm{~g} / 24 \mathrm{~h}$ \\
\hline Fair & $\leq 150 \mathrm{mg} / 100 \mathrm{ml}$ & $\leq 200 \mathrm{mg} / 100 \mathrm{ml}$ & $\leq 180 \mathrm{mg} / 100 \mathrm{ml}$ & $\leq 10-20 \mathrm{~g} / 24 \mathrm{~h}$ \\
\hline Poor & $\leq 220 \mathrm{mg} / 100 \mathrm{ml}$ & $\leq 280 \mathrm{mg} / 100 \mathrm{ml}$ & $\leq 250 \mathrm{mg} / 100 \mathrm{ml}$ & $\leq 30-40 \mathrm{~g} / 24 \mathrm{~h}$ \\
\hline Negative & $>220 \mathrm{mg} / 100 \mathrm{ml}$ & $>280 \mathrm{mg} / 100 \mathrm{ml}$ & $>250 \mathrm{mg} / 100 \mathrm{ml}$ & $>30-40 \mathrm{~g} / 24 \mathrm{~h}$ \\
\hline
\end{tabular}

Table 2.

\begin{tabular}{|c|c|c|c|c|}
\hline & Phenformin & Glibenclamide & Chlorpropamide & Glipizide \\
\hline Excellent control & 6 & 8 & 7 & 6 \\
\hline $\begin{array}{l}\text { Good Control } \\
\text { Fair or unsatis- }\end{array}$ & 4 & 3 & 2 & 4 \\
\hline factory control & 5 & 2 & 2 & $4 \ldots$ \\
\hline $\begin{array}{l}\text { Cross over to } \\
\text { glipizide }\end{array}$ & 5 & 2 & 2 & 2 switched to insulin \\
\hline Satisfactory control & 4 & 2 & 1 & 2 crossed over to \\
\hline Unsatisfactory control & 1 & 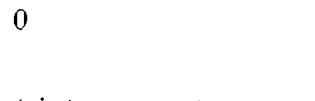 & 7 & $\begin{array}{l}\text { glibenclamide (1 satis- } \\
\text { factory and } 1 \\
\text { unsatisfactory control) }\end{array}$ \\
\hline Drop-outs & 0 & $\begin{array}{l}1 \text { intercurrent } \\
\text { infection } \\
1 \text { did not return }\end{array}$ & $\begin{array}{l}2 \text { hypoglycaemia } \\
1 \text { persistent } \\
\text { nausea, } 1 \text { exitus }\end{array}$ & $\begin{array}{l}1 \text { patient could be } \\
\text { controlled with } \\
\text { diet alone }\end{array}$ \\
\hline Side effects & $\begin{array}{l}1 \text { diarrhoea } \\
3 \text { patients } \\
\text { had nausea, } \\
\text { anorexia and } \\
\text { vomiting }\end{array}$ & $\begin{array}{l}1 \text { patient } \\
\text { had nausea }\end{array}$ & $\begin{array}{l}1 \text { patient } \\
\text { had nausea }\end{array}$ & No complaints \\
\hline Laboratory tests & No anomalies & $\begin{array}{l}1 \text { macrocytic anemia } \\
1 \text { renal insuffi- } \\
\text { ciency developing } \\
\text { under therapy }\end{array}$ & No anomalies & $\begin{array}{l}1 \text { increase of } \\
\text { triglycerides } \\
\text { (temporary of } \pm 50 \mathrm{mg} \% \text { ) }\end{array}$ \\
\hline $\begin{array}{l}\text { Number of newly } \\
\text { diagnosed patients }\end{array}$ & $6 / 15$ & 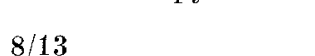 & $6 / 11$ & $7 / 14$ \\
\hline Mean dose & $\begin{array}{l}100 \mathrm{mg} / \mathrm{d} \\
(50 \mathrm{mg} \text { b.d.) }\end{array}$ & $\begin{array}{l}7.5 \mathrm{mg} / \mathrm{d} \\
\text { (mostly o.d.) }\end{array}$ & $250 \mathrm{mg}$ o.d. & $\begin{array}{l}10 \mathrm{mg} / \mathrm{d} \\
\text { (o.d. or b.d.) }\end{array}$ \\
\hline $\begin{array}{l}\text { Maximum dose } \\
\text { administered }\end{array}$ & $150 \mathrm{mg} / \mathrm{d}$ & $15 \mathrm{mg} / \mathrm{d}$ & $500 \mathrm{mg} / \mathrm{d}$ & $30 \mathrm{mg} / \mathrm{d}$ \\
\hline
\end{tabular}

\section{Phenformin Group}

Phenformin is a biguanide with a different kind of action from that of the sulfonylurea compounds and likely to be most active in a selected group of diabetics, i.e. the more obese diabetic patients. As the drugs, in accordance with the method used, were randomly allocated without reference to the initial weight, phenformin could give good or bad results depending on the type of patient to whom it was ad- showed a "good" or "excellent" degree of control with a small dose $(5-10 \mathrm{mg})$ of the drug.

The classical gastro-intestinal side effects of the biguanides were troublesome only in the patients receiving $150 \mathrm{mg} / \mathrm{day}$ and disappeared after withdrawal of the drug.

In the patients satisfactorily controlled with phenformin, the commonest dosage used was $100 \mathrm{mg} /$ day. In this group only one patient showed a short episode of diarrhoea that cleared spontaneously. 


\section{Glibenclamide Group}

The overall impression of this group confirms our clinical experience that glibenclamide is a potent antidiabetic drug: 11 of the relevant 13 patients achieved "good" or "excellent" control with a small dose of the drug $(2.5 \rightarrow 5 \mathrm{mg})$. It should be noted that the two glibenclamide (15 mg) "primary failures" who are currently being treated with glipizide (12.5 and $20 \mathrm{mg}$ ) have now achieved "fair" control. There were no significant weight changes in this group. The fact that no hypoglycemic symptoms were observed can be ascribed to the special care taken in increasing the dose of the drug following the numerous incidents of hypoglycemia reported in the literature. On the other hand, the absence of symptoms in this study proves that, with adequate precautions, glibencalmideinduced hypoglycemia can be avoided.

An unexplained episode of renal insufficiency, probably not related to the drug therapy, was observed. We were impressed by the development during treatment of a macrocytic-megaloblastic anaemia in a patient known to have a normal blood film at the beginning of the study. The frequent association of pernicious anemia and diabetes is a well-known fact but the hematological investigations in this case seemed to indicate a deficiency in folic acid. Further studies are currently under way.

\section{Chlorpropamide Group}

All patients with satisfactory control gained weight but part of this can be explained by the disappearance of glucosuria. The effectiveness of the dose of $250 \mathrm{mg}$ mane, confirms our clinical experience with the drug. The potency and the necessity for special attention was confirmed by the fact that two patients developed typical hypoglycemia with low doses $(125 \mathrm{mg})$.

A side effect, unusual in our experience and seen in only one patient was persistent nausea which necessitated the withdrawal of the drug.

It should be noted that, as in the other groups, no symptoms of antabuse effect were recorded.

As in the previous groups, the "primary failures" were treated afterwards with glipizide, but the results were less impressive than in the phenformin group. Indeed, as in the glibenclamide group, only "fair" control could be obtained and this time only in one patient.

\section{Glipizide Group}

The general impression was that of a drug that was easy to handle. The doses were individually adjusted from 2.5 to $20 \mathrm{mg}$. In about half the cases two administrations $(8.00 \mathrm{a} . \mathrm{m}$. and $6.00 \mathrm{p.m}$.) were necessary to cover the $24 \mathrm{~h}$. Our first impression was that the drug's, potency was somewhat less than that of glibenclamide and chlorpropamide since four fair or unsatisfactory results were observed compared with only two in the other two groups. However, two of these "failures" were probably "insulin-dependent" patients and the other two were only "fairly" well controlled when treated with glibenclamide. A more valid evaluation will therefore only be possible after longer observation of the patients in the various groups.

Tolerance was good. No hypoglycemic symptoms or antabuse effects were noted, and there were no major abnormalities of hematology or biochemistry.

The weight changes were not significant and the subjective feelings of the patient were good.

\section{Conclusions}

It is, of course, impossible to draw any final conclusions on the real value of glipizide as an antidiabetic drug from such a small series of patients treated during a period of only three months; however, we can probably conclude, at this stage of our study, that:

1. Glipizide administered at a dose of $5-20 \mathrm{mg} / \mathrm{d}$ seems to be an effective antidiabetic drug.

2 . In patients in whom a good or excellent degree of control was obtained the mean dose used was $10 \mathrm{mg} /$ day with a range of 2.5 to $15 \mathrm{mg} /$ day. None of the responders in our study required the recommended maximum dose of $20 \mathrm{mg}$ per day.

3. Four "primary failures" with phenformin (with the restrictions mentioned above), one with chlorpopramide and two with glibenclamide, were satisfactorily controlled with glipizide. This fact alone is important enough to continue the study because it widens the therapeutic possibilities of oral antidiabetic treatment, especially since no important side effects of the drug were noted.

\section{References}

1. Ambrogi, V., Bloch, K., Daturi, S., Griggi, E., Logemann, W., Parenti, M.A., Rabini, T., Tommasini, R.: New oral antidiabetic drugs. Part I. ArzneimittelForsch. 21, 200-204 (1971)

2. Ambrogi, V., Bloch, K., Cozzi, P., Daturi, S., Logemann, W., Parenti, M. A., Tommasini, R. : New oral antidiabetic drugs. Part II. Arzneimittel-Forsch. 21, 204208 (1971)

3. Marigo, S., Del Nevo, G., Dinni, P.P., Sacchetti, G.: Pharmacological methods for evaluating a new hypoglycemic agent in humans. Arzneimittel-Forsch. 21, $215-220(1971)$

4. Pedrazzi, E., Pisani-Cerretti, A., Losi, S., Bommartini, E., Artini, D., Emanueli, A.: Evaluation in hospitalised subjects of a new hypoglycemic sulfonylurea: glidiazinamide. Arzneimittel-Forsch. 21, 220-225 (1971)

Dr. J. De Leeuw

Antwerp Diabetes Study Group

Elf Novemberstraat, 43

B-2060 Merksem

Belgium

Responsible for the text: Prof. Dr. W. Creutzfendr, Med. Universitätsklinik, Humboldtallee 1, D-34 Göttingen/F.R.G. Prof. Dr. K. Schörfind, Zentrum der Inneren Medizin, Theodor-Stern-Kai 7, D-6 Frankfurt 70/F. R. G. Responsible for advertisements: L. Sregex, G. Maritin, D-1000 Berlin 15, Kurfürstendamm 237. Springer-Verlag, Berlin, Heidelberg, New York. Printed in Germany by Druckerei Georg Appl, Wemding/Schwaben. 